\title{
COMPARISON BETWEEN CHANGES OF PARAFOVEAL OUTER PLEXIFORM-INNER NUCLEAR LAYERS THICKNESS AND CHANGES OF PARAFOVEAL GANGLION CELL LAYER THICKNESS AFTER INTRAVITREAL RANIBIZUMAB INJECTION FOR DIABETIC AND BRANCH VEIN OCCLUSION RELATED MACULOPATHY
}

By

\section{Mostafa Farid Mohammed Al-Neklawy}

Ophthalmology Department, Faculty of Medicine, Al-Azhar University, Cairo, Egypt

E-mail: mostafafarid80@gmail.com; Tel.:00201061014849-00966545636346

\begin{abstract}
Background: Optical coherence tomography (OCT) has enabled objective measurement of macular thickness in diabetic and branch retinal vein occlusion (BRVO) associated macular edema (ME). Recent advances in OCT with higher resolution enabled segmentation of the individual retinal layers, quantification of the thickness of retinal layers and qualitative evaluation of lesions in individual layers.

Objectives: Studying the changes of parafoveal outer plexiform-inner nuclear layers thickness (OPINLT) and changes of parafoveal ganglion cell layer (GCL) thickness at the thickest parafoveal point after single injection of ranibizumab in patients with ME caused by diabetic retinopathy (DR) or BRVO.

Patients and Methods: The present study included 36 eyes of 30 patients ( 21 males and 9 females, mean age was $52.87 \pm 7.56$ years old $)$. All patients had single intravitreal injection of $0.5 \mathrm{mg}(0.05 \mathrm{~mL}$ of $10 \mathrm{mg} / \mathrm{mL})$ of ranibizumab (bilaterally in 6 patients and unilaterally in 24 patients) for treatment of ME caused by DR or BRVO. OCT images were taken preoperatively, and one month after intravitreal ranibizumab injection for all participants using spectral OCT SLO combination imaging system. Foveal thickness was measured. Parafoveal measurements were obtained at the thickest parafoveal point (1200 ? $\mathrm{m}$ from foveal center) in the superior, nasal, inferior and temporal parafoveal sectors. Parafoveal measurements included parafoveal thickness, OPINLT, isolated GCL thickness and GCL-IPL thickness (GCIPLT).

Results: The study included 30 eyes with diabetic ME caused by moderate to severe non-proliferative diabetic retinopathy (NPDR) or early proliferative diabetic retinopathy (PDR); 17 eyes with cystoid macular edema (CME) and 13 eyes with diffuse macular edema (DME), in addition to 6 eyes with CME due to BRVO. As regards changes of participants' best corrected visual acuity (BCVA) and foveal thickness, there was a statistically significant improvement in BCVA mean value from $0.36 \pm 0.19$ preoperatively to be $0.7 \pm 0.27$ one month after injection, and statistically significant decrease in mean foveal thickness from $342.64 \pm 110.04 ? \mathrm{~m}$ preoperatively to be $249.55 \pm 68.90 ? \mathrm{~m}$ one month after injection. As regards total parafoveal thickness, there was statistically significant decrease in mean parafoveal thickness of the participants in each parafoveal sector after injection and the postoperative parafoveal thickness mean values
\end{abstract}


were higher in the superior and nasal sectors. As regards detailed segmented parafoveal measurements, there were statistically significant decrease in both OPINLT and GCIPLT mean values in all parafoveal sectors after injection. By further analysis of isolated GCL, the present study results have shown that the changes of GCL mean thickness in each parafoveal sector were not statistically significant. In addition, preoperative and postoperative GCL thickness mean values were higher in the superior and nasal sectors.

Conclusion: OPINLT and GCIPLT decreased significantly at the thickest point of parafoveal area after single intravitreal ranibizumab injection for treatment of ME caused by DR or BRVO, while isolated GCL thickness did not change significantly after injection. It was proven also that GCL which contains the cell bodies of ganglion cells (GCs) was proven to be the least affected layer by ME.

Key words: outer plexiform layer, inner nuclear layer, ganglion cell layer, inner plexiform layer, parafoveal thickness, ranibizumab, diffuse macular edema, cystoid macular edema, diabetic retinopathy, branch retinal vein occlusion.

\section{INTRODUCTION}

Macular edema (ME) is the main cause of visual loss in diabetic patients. Retinal neuronal abnormalities are present well before the retinal microvascular injury (Murakami and Yoshimura, 2013).

Somfai et al. (2007) showed significant thinning of macular nerve fiber layer (NFL) in eyes with diffuse macular edema (DME). Increased vasopermeability occurs as a result of breakdown of the blood retinal barrier (BRB). Altered BRB leads to interstitial fluid accumulation within the retina and, in some cases, cyst formation, particularly in the perifoveal retina (Murakami and Yoshimura, 2013).

Spectral domain optical coherence tomography (SD-OCT) is fast becoming the current standard of care for the detection and assessment of diabetic ME. Retinal thickness measurements by SDOCT have also been used for deciding the management and monitoring of the disease. Recent advances in SD-OCT have provided better delineation of the structural changes and fine lesions in the individual retinal layers (Tripathy et al., 2015).

The morphological patterns of diabetic ME on OCT are generally classified into sponge-like DME, cystoid macular edema (CME), subretinal detachment, and vitreomacular interface abnormalities (Yasser and Heba, 2013).

Clinically, significant macular edema (CSME) is a clinical diagnosis and is defined by the Early Treatment Diabetic Retinopathy Study (ETDRS) as: Retinal thickening within $500 \mu \mathrm{m}$ of the macular center, hard exudates within $500 \mu \mathrm{m}$ of the macular center with adjacent retinal thickening or one or more disc diameters of retinal thickening, part of which is within one disc diameter of the macular center (Nguyen et al., 2012).

Retinal vein occlusion (RVO) is the second most common cause of retinal vascular disease after diabetic retinopathy (DR). Chronic ME is the most common cause of persistent poor visual acuity following branch retinal vein occlusion (BRVO) (Gerding et al., 2015).

Anti-vascular endothelial growth factors (anti-VEGF) therapy has been established as a first-line therapy for diabetic ME and indicated for treatment of patients with ME following branch retinal vein occlusion (BRVO). The overall efficacy of anti-VEGF therapy for both anatomic and functional improvement has 
been established in multiple studies (Ruia et al., 2016). The central retinal thickness is correlated modestly with visual impairment and changes paradoxically after treatments compared to the visual acuity (Murakami and Yoshimura, 2013).

The present work aimed to compare the changes of parafoveal combined outer plexiform-inner nuclear layers thickness (OPINLT), with the changes of parafoveal ganglion cell layer (GCL) thickness after intravitreal single injection of Ranibizumab in patients with macular edema (ME) caused by diabetic retinopathy (DR) or branch retinal vein occlusion (BRVO).

\section{PATIENTS AND METHODS}

This prospective non-randomized interventional study included 36 eyes of 30 patients (21 males and 9 females, mean age was $52.87 \pm 7.56$ years old; range $(\mathrm{R})$ : 30-62 years). Six patients had bilateral injection and 24 patients had unilateral injection of intravitreal ranibizumab in Almouwasat Hospital (Jubail Industrial city, KSA) during the period between October, 2017 and March, 2018, for treatment of ME caused by moderate to severe non proliferative diabetic retinopathy (NPDR), early proliferative diabetic retinopathy (PDR) or BRVO. All patients provided informed consents prior to injection. Patients with uncontrolled diabetes mellitus (DM) or hypertension at time of injection, patients with abnormal glycosylated hemoglobin ( $\mathrm{Hb} \mathrm{A} 1 \mathrm{c}$ ), and patients using systemic medications which may cause retinopathy such as chloroquine were excluded. Patients with media opacity such as corneal opacities or dense cataract which may cause artifacts and reduction of the signal strength of
OCT images, patients with advanced DR such as diabetic vitreous hemorrhage or vitreomacular traction, patients with age related maculopathy, patients with myopic chorioretinal degenerations and patients with advanced open angle glaucoma or rubeotic glaucoma were excluded. Patients with history of cataract surgery in the last year before injection, patients with history of previous intravitreal injections and non-responders after the present study ranibizumab injection were also excluded. Detailed personal history, general medical history, and detailed ophthalmologic history (including history of ocular diseases, medications, investigations, laser treatment and ocular surgeries) were taken at base-line for all participants. Full ophthalmologic examination including the refraction, unaided visual acuity, best corrected visual acuity (BCVA); using Snellen's decimal format, pupillary examination, slit lamp examination of the anterior segment, applanation tonometry, and dilated fundus examination of the macula, disc, retinal blood vessels and retinal periphery by slit lamp biomicroscopy were done at base line examination and at the follow up visits after injection.

Anti-VEGF treatment: All eyes had single intravitreal injection of $0.5 \mathrm{mg}$ ranibizumab $(0.05 \mathrm{~mL}$ of $10 \mathrm{mg} / \mathrm{mL}$ LUCENTIS solution).

Macular OCT: OCT images were taken preoperatively and one month postoperatively for all participants using spectral OCT SLO combination imaging system (OPKO instrumentation, USA). The foveal thickness was measured. The parafoveal measurements were obtained at the thickest point $1200 ? \mathrm{~m}$ from foveal 
center in the four parafoveal sectors according to the ETDRS macular grid. The parafoveal measurements in the present study included parafoveal thickness, OPINLT, isolated GCL thickness and combined ganglion cellinner plexiform layers thickness (GCIPLT).

Statistical Analysis: All preoperative and postoperative data including the best corrected visual acuity, foveal thickness and parafoveal measurements of the participants were statistically analyzed using GraphPad Software paired t-test. The data obtained including the mean, range (R), and the standard deviation (S.D) were used to obtain probability (P) value, and $\mathrm{P}$ value less than 0.05 was considered statistically significant.

\section{RESULTS}

The present study included 24 patients with diabetic maculopathy (16 males and 8 females, mean duration of diabetes was 13.4 \pm 5.96 , R: $8-36$ ), and six patients with BRVO (5 males and one female). As regard patients with diabetic maculopathy; 8 patients were only diabetic, 9 patients were diabetic and hypertensive, and 7 patients were diabetic, hypertensive and hyperlipidemic. Eyes with DR included 30 eyes: 7 eyes with moderate NPDR, 15 eyes with severe NPDR and 8 eyes with early PDR (according to ETDRS grading). As regards preoperative diabetic ME 17 eyes had CME and 13 eyes had DME. As regards patients with BRVO three patients were hypertensive and the other three patients were hypertensive and hyperlipidemic. Eyes with BRVO included 6 eyes: two eyes with upper temporal BRVO, 2 eyes with lower temporal BRVO, and another two eyes with macular branch vein occlusion
(BVO). All included eyes with BRVO had preoperative CME. No patients had postoperative complication or significant rise in intraocular pressure (IOP).

There was a statistically significant improvement in BCVA mean value of the participants from $0.36 \pm 0.19$ preoperatively to be $0.7 \pm 0.27$ one month after injection.

There was a statistically significant decrease in the mean foveal thickness of the participants from $342.64 \pm 110.04 ? \mathrm{~m}$ preoperatively to be $249.55 \pm 68.90 ? \mathrm{~m}$ one month after injection.

There was a statistically significant decrease in mean parafoveal thickness of the participants at the thickest point in each parafoveal sector. Postoperative parafoveal thickness mean values were relatively higher in the superior and nasal sectors (Table 1). 
Table (1): Changes of parafoveal thickness in the parafoveal sectors (mean \pm S.D)

\begin{tabular}{|c|c|c|c|}
\hline Thickness & $\begin{array}{c}\text { Preoperative } \\
\text { parafoveal mean } \\
\text { thickness }\end{array}$ & $\begin{array}{c}\text { Postoperative } \\
\text { parafoveal mean } \\
\text { thickness }\end{array}$ & P Value \\
\hline Superior & $396.67 \pm 84.92 ? \mathrm{~m}$ & $343.75 \pm 54.98 ? \mathrm{~m}$ & $<0.05$ \\
\hline Nasal & $422.92 \pm 128 ? \mathrm{~m}$ & $350.58 \pm 67.81 ? \mathrm{~m}$ & $<0.05$ \\
\hline Inferior & $415.83 \pm 111.78 ? \mathrm{~m}$ & $342.92 \pm 76.94 ? \mathrm{~m}$ & $<0.05$ \\
\hline Temporal & $376.67 \pm 113.02 ? \mathrm{~m}$ & $328.75 \pm 92.62 ? \mathrm{~m}$ & $<0.05$ \\
\hline
\end{tabular}

There was a statistically significant decrease in mean OPINLT of the participants in each parafoveal sector.
Postoperative OPINLT mean values were relatively higher in the superior and nasal sectors (Table 2).

Table (2): Changes of parafoveal OPINLT in the parafoveal sectors (mean \pm S.D)

\begin{tabular}{|c|c|c|c|}
\hline $\begin{array}{l}\text { OPINLT } \\
\text { Parafoveal } \\
\text { sectors }\end{array}$ & $\begin{array}{c}\text { Preoperative } \\
\text { mean thickness }\end{array}$ & $\begin{array}{c}\text { Postoperative } \\
\text { mean thickness }\end{array}$ & P Value \\
\hline Superior & $112.08 \pm 44.28 ? \mathrm{~m}$ & $85 \pm 29.42 ? \mathrm{~m}$ & $<0.05$ \\
\hline Nasal & $104.17 \pm 39.27 ? \mathrm{~m}$ & $73.33 \pm 10.62 ? \mathrm{~m}$ & $<0.05$ \\
\hline Inferior & $100.42 \pm 35.34 ? \mathrm{~m}$ & $71.33 \pm 16.48 ? \mathrm{~m}$ & $<0.05$ \\
\hline Temporal & $84.58 \pm 29.09 ? \mathrm{~m}$ & $63.33 \pm 13.63 ? \mathrm{~m}$ & $<0.05$ \\
\hline
\end{tabular}

The changes of participants GCL mean thickness in each parafoveal sector were not statistically significant. Preoperative and postoperative GCL thickness mean values were higher in the superior and nasal sectors (Table 3 ).

Table (3): Changes of parafoveal GCL thickness in the parafoveal sectors (mean \pm S.D)

\begin{tabular}{|c|c|c|c|}
\hline \multicolumn{1}{|c|}{ GCL thickness } & $\begin{array}{c}\text { Preoperative } \\
\text { Parafoveal } \\
\text { sectors }\end{array}$ & $\begin{array}{c}\text { Postoperative } \\
\text { mean thickness }\end{array}$ & P Value \\
\hline Superior & $72.92 \pm 20.33 ? \mathrm{~m}$ & $70.83 \pm 22.66 ? \mathrm{~m}$ & $>0.05$ \\
\hline Nasal & $71.43 \pm 7.61 ? \mathrm{~m}$ & $70 \pm 9.87 ? \mathrm{~m}$ & $>0.05$ \\
\hline Inferior & $68.46 \pm 15.18 ? \mathrm{~m}$ & $65.42 \pm 16.62 ? \mathrm{~m}$ & $>0.05$ \\
\hline Temporal & $64.38 \pm 12.36 ? \mathrm{~m}$ & $61.88 \pm 9.19 ? \mathrm{~m}$ & $>0.05$ \\
\hline
\end{tabular}

There was a statistically significant decrease in mean GCIPLT of the participants in each parafoveal sector.
Postoperative GCIPLT mean values were higher in the superior and nasal sectors (Table 4). 


\section{MOSTAFA FARID MOHAMMED AL-NEKLAWY}

Table (4): Changes of parafoveal GCIPLT in the parafoveal sectors (mean \pm S.D)

\begin{tabular}{|c|c|c|c|}
\hline \multicolumn{1}{|c|}{ GCIPLT } & $\begin{array}{c}\text { Preoperative } \\
\text { Parafoveal } \\
\text { sectors }\end{array}$ & $\begin{array}{c}\text { Postoperative } \\
\text { mean thickness }\end{array}$ & P Value \\
\hline Superior & $105 \pm 14.41 ? \mathrm{~m}$ & $94.44 \pm 17.23 ? \mathrm{~m}$ & $<0.05$ \\
\hline Nasal & $105.63 \pm 11.26 ? \mathrm{~m}$ & $101.88 \pm 13.25 ? \mathrm{~m}$ & $<0.05$ \\
\hline Inferior & $95 \pm 10.74 ? \mathrm{~m}$ & $89.89 \pm 11.96 ? \mathrm{~m}$ & $<0.05$ \\
\hline Temporal & $100 \pm 12.77 ? \mathrm{~m}$ & $88.75 \pm 11.63 ? \mathrm{~m}$ & $<0.05$ \\
\hline
\end{tabular}

\section{Case report}

Case no. (1): 37 years old diabetic and hypertensive male with preoperative right CME and left DME (Figures: 1-5):
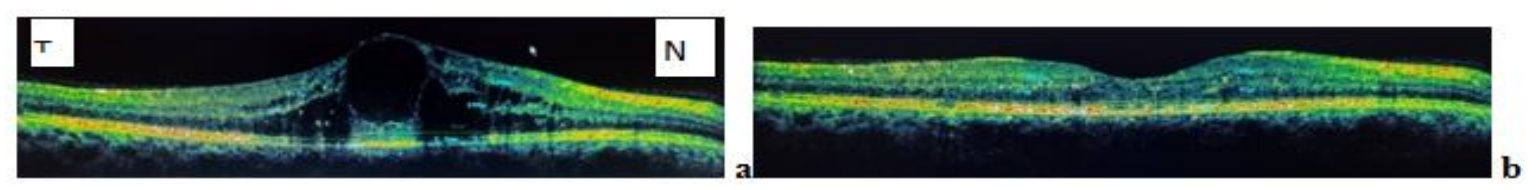

Figure (1): Preoperative (a) and postoperative (b) horizontal line scan of right macular OCT showed marked decrease of OPINLT and GCIPLT in parafoveal temporal and nasal sectors after injection (T: temporal, N:nasal).
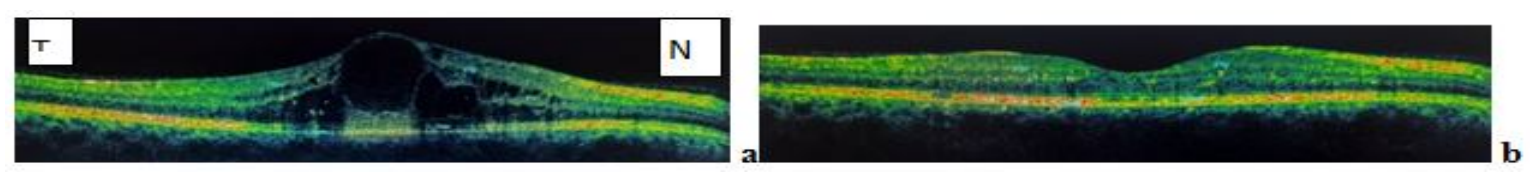

Figure (2): Preoperative (a) and postoperative (b) horizontal line scan of right macular OCT showed mild decrease of GCL thickness in parafoveal temporal and nasal sectors after injection.
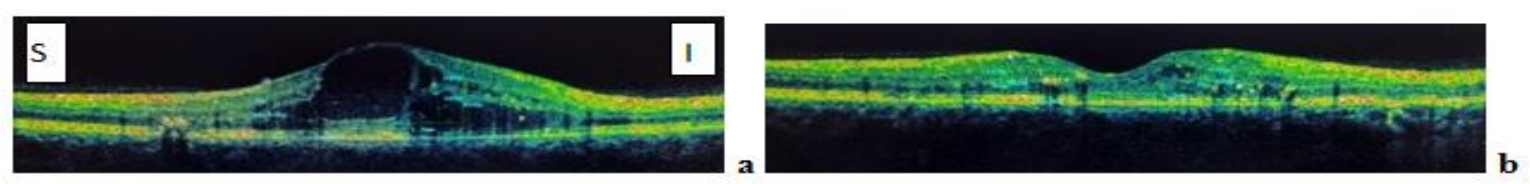

Figure (3): Preoperative (a) and postoperative (b) vertical line scan of right macular OCT showed marked decrease of OPINLT and GCIPLT in parafoveal superior and inferior sectors after injection ( $\mathrm{S}$ : superior, I: inferior).
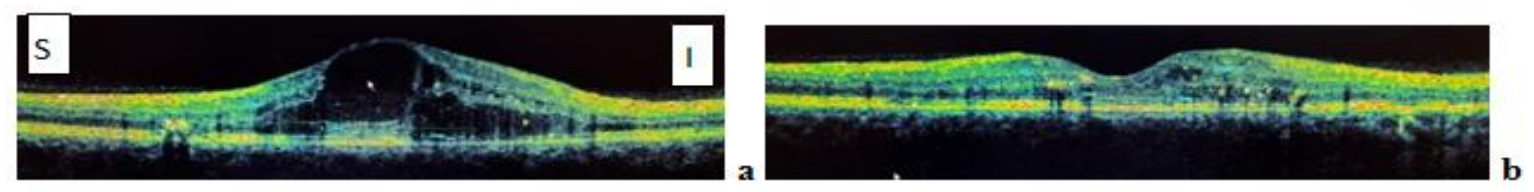

Figure (4): Preoperative (a) and postoperative (b) vertical line scan of right macular OCT showed relatively stable GCL thickness in parafoveal superior and inferior sectors after injection. 

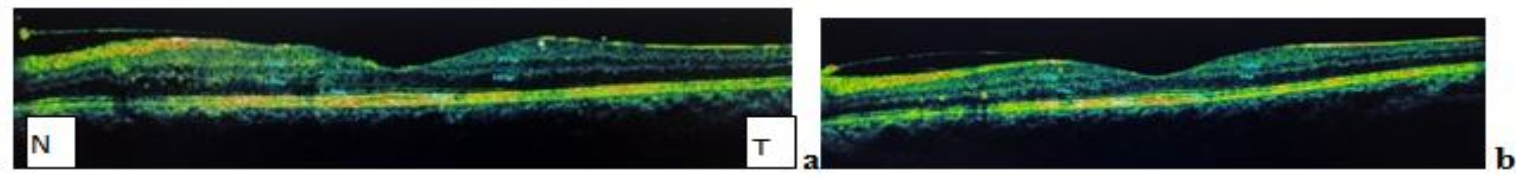

Figure (5): Preoperative (a) and postoperative (b) horizontal line scan of left macular OCT showed marked decrease of OPINLT and GCIPLT in parafoveal nasal and temporal sectors after injection.

Case no. (2): 48 years old hypertensive male with preoperative right inferior macular BVO (Figures: 6-7):
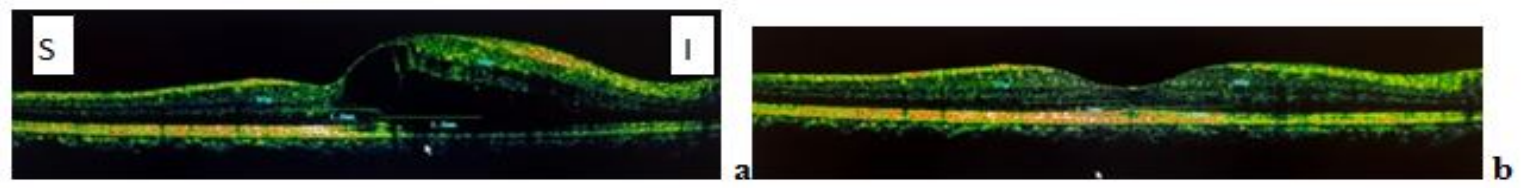

Figure (6): Preoperative (a) and postoperative (b) horizontal line scan of right macular OCT showed marked decrease of OPINLT and GCIPLT in parafoveal temporal and nasal sectors after injection.
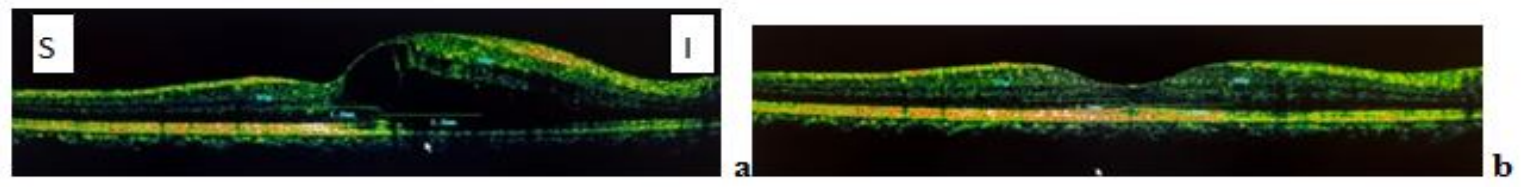

Figure (7): Preoperative (a) and postoperative (b) vertical line scan of right macular OCT showed mild decrease of GCL thickness in the superior parafoveal sector and mild increase of GCL thickness in the inferior parafoveal sector after injection.

Case no. (3): 38 years old diabetic female with preoperative left diffuse and CME (Figure: 8):
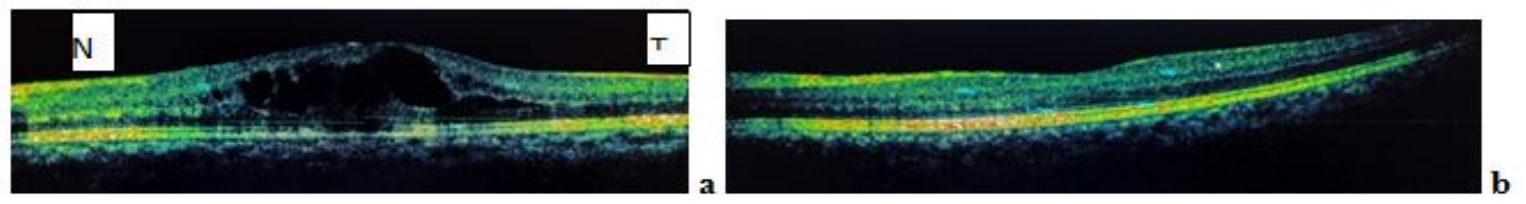

Figure (8): Preoperative (a) and postoperative (b) horizontal line scan of left macular OCT showed mild decrease of GCL thickness in the nasal parafoveal sector and stable GCL thickness in the temporal parafoveal sector after injection. (While OPINLT and GCIPLT showed marked decrease after injection). 
Case no. (4): 53 years old hypertensive male with left upper temporal BRVO (Figures: 910):
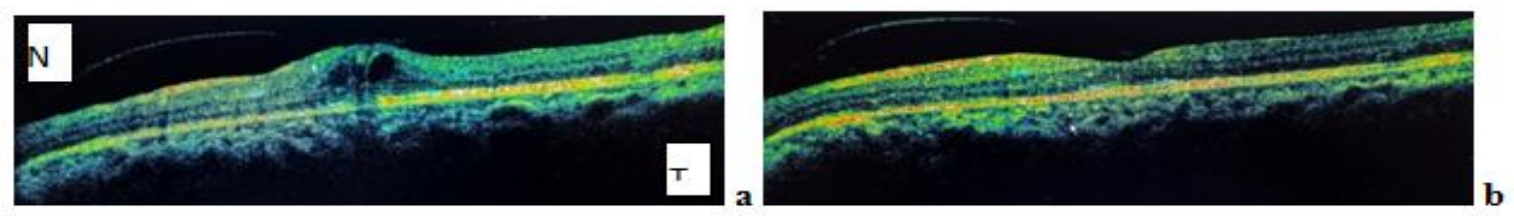

Figure (9): Preoperative (a) and postoperative (b) horizontal line scan of left macular OCT showed stable GCL thickness in the nasal parafoveal sector and mild increase of GCL thickness in the temporal parafoveal sector after injection. (While OPINLT and GCIPLT showed marked decrease after injection).
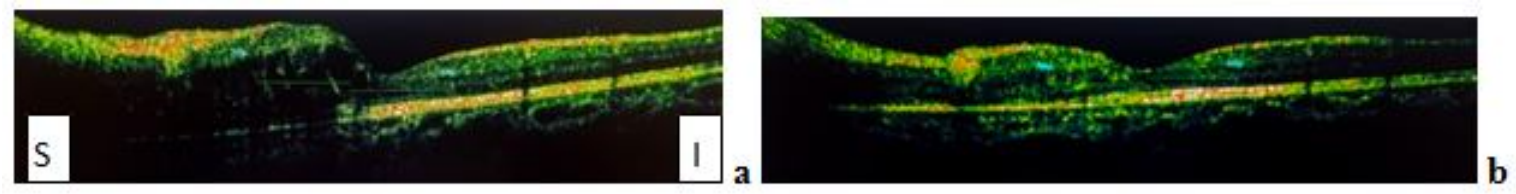

Figure (10): Preoperative (a) and postoperative (b) vertical line scan of left macular OCT showed stable GCL thickness in the superior and inferior parafoveal sectors after injection. (While OPINLT and GCIPLT showed marked decrease after injection).

\section{DISCUSSION}

OCT shows several types of foveal morphologies in diabetic and BRVO associated ME. Cystoid spaces are formed mainly in the INL and OPL, which has been supported by histologic reports. Sponge-like retinal swelling at the fovea occurs in the OPL. SD-OCT has enhanced the understanding of retinal anatomical changes in DR (Trichonas and Kaiser, 2014).

Ana et al. (2010) reported that the thickness of OPL and INL in normal subjects were relatively constant in the parafoveal area. Jampel et al. (2009) reported that the normal average distance from the foveal pit to the thickest point in the parafoveal annulus was $1240 \pm 138 ? \mathrm{~m}$ where GCL might be 8 to 10 cells thick, and this height of parafoveal annulus relative to the foveal pit did not change with age and would, therefore, seem to be a better marker of neuronal tissue health than the average retinal thickness of the entire macula.

Murakami and Yoshimura. (2013) have reported that significant thinning of macular NFL was found in eyes with diabetic DME supporting the view that there may be neuronal loss in NFL in eyes with DR. OCT images of the present study have shown marked thinning of NFL due to CME or DME. In addition, ganglion cell synapses of the IPL were proved to be the largest part of each ganglion cell; forming an extensive branching dendritic arbour, while the cell body in (GCL) and axon in (NFL) are relatively small compared to this dendritic tree (Kotowski et al., 2012). So, the present study considered analysis of changes of parafoveal GCIPLT in addition to parafoveal isolated GCL thickness. 
In the light of the present study, the foveal thickness, parafoveal thickness, OPINLT and GCIPLT decreased significantly after single ranibizumab injection. Isolated GCL (which contains the ganglion cells (GCs) bodies) did not decrease in thickness significantly after injection, so the decrease in GCIPLT thickness was mostly due to thinning of IPL (the layer of GCs dendrites).

Ebneter et al. (2016) reported that decrease of central retinal thickness after treatment of diabetic ME using intravitreal ranibizumab injection was associated with better visual acuity gain. The results of the present study were supportive to these results as postoperative decrease in mean foveal thickness of the participants was associated with improvement of BCVA mean value.

Waris et al. (2015) reported that the superior and nasal quadrants were thickest at the parafoveal and perifoveal areas of normal individuals. Mwanza et al. (2011) reported that parafoveal mean GCIPLT was higher in the superior and nasal sectors. The results of the present study were supportive to the results of the above-mentioned authors as parafoveal thickness and GCIPLT measurements after treatment were higher in the superior and nasal sectors.

By analysis of the present study parafoveal measurements after treatment, the mean parafoveal thickness, mean GCL thickness and mean GCIPLT were higher than normal parafoveal average values recorded by different studies because the present study evaluated these parafoveal measurements at the thickest parafoveal point.
By analysis of parafoveal GCL thickness changes in the present study, minority of eyes had thicker GCL after injection. It may be due to optical variations caused by reduction of edema in surrounding retinal layers .

Beck et al. (2016) showed that GCL thickness decreased significantly after unilateral long term therapy with ranibizumab for subfoveal and juxtafoveal neovascular age related macular degeneration compared to the non-injected fellow eye, while the decrease in retinal NFL was not significant. The present study showed that there was minor nonsignificant decrease in GCL thickness at the thickest point in all sectors of the middle ring of the ETDRS macular grid (the parafoveal area) after single injection of ranibizumab for treatment of DME or CMD in patients with DR or BRVO, while there was significant decrease in GCIPLT. The progressive thinning of GCL in the study of (Beck et al., 2016) was expected to be due to repeated injection of ranibizumab with IOP fluctuations, the degenerative nature of age related maculopathy or due to different GCL thickness monitoring location.

Somfai et al. (2007) reported significant increase of GCIPLT and outer nuclear layer (ONL) thickness in eyes with DME. The present study showed increased parafoveal GCIPLT and OPINLT in eyes with DME or CME prior to injection, while the present study didn't include ONL thickness analysis.

\section{CONCLUSION}

At the parafoveal height, OPINLT and GCIPLT decreased significantly after 
single intravitreal ranibizumab injection for treatment of ME caused by $\mathrm{DR}$ or BRVO, while isolated GCL thickness did not change significantly after injection. GCL which contains the cell bodies of GCs was proven to be the least affected layer by ME. Further histologic and OCTbased larger studies for analysis of GCL changes during ME and after anti-VEGF therapy may be recommended.

\section{REFERENCES}

1. Ana $L$, Zhang $C$, Zelkha $R$ and Shahidi $M$ (2010): Thickness mapping of retinal layers by spectral domain optical coherence tomography. Am J Ophthalmol., 150 (6): 849-855.

2. Beck M, Munk MR, Ebneter A, Wolf S and Zinkernagel MS (2016): Retinal ganglion cell layer change in patients treated with antivascular endothelial growth factor for neovascular age-related macular degeneration. Am J Ophthalmol., 167 (1): 10-17.

3. Ebneter A, Wolf $S$, Abhishek $J$ and Zinkernagel MS (2016): Retinal layer response to ranibizumab during treatment of diabetic macular edema: thinner is not always better. Retina, 36 (7): 1314-1323.

4. Gerding H, Mones J and Tadayoni R (2015): Ranibizumab in retinal vein occlusion: treatment recommendations by an expert panel. British Journal of Ophthalmology, 99 (1): 297304.

5. Jampel J, Vitale S, Ding $Y$, Knezevich $F$, Quigley H and Zeimer R (2009): Retinal thickness in eyes of older normal individuals and its implication for the diagnosis of glaucoma. Journal of glaucoma, 18 (1): 37-43.

6. Kotowski J, Folio LS, Wollstein G, Ishikawa $H$, Ling Y, Bilonick RA, Kagemann $L$ and Schuman JS (2012): Glaucoma discrimination of segmented cirrus spectral domain optical coherence tomography macular scans. Br J Ophthalmol., 96 (11): 1420-1425.

7. Murakami $T$ and Yoshimura $N$ (2013): Structural changes in individual retinal layers in diabetic macular edema. J Diabetes Res., 10 (1): 1155-1166.
8. Mwanza JC, Durbin MK, Budenz DL, Christopher A, Girkin CA, Christopher K, Leung CK, Liebmann JM, Peace JH, John S, Werner JS and Wollstein G (2011): Profile and predictors of normal ganglion cell-inner plexiform layer thickness measured with frequency-domain optical coherence tomography. Investigative Ophthalmology \& Visual Science, 52 (1): 7872-7879.

9. Nguyen QD, Brown DM, Marcus DM, Boyer DS, Patel S, Feiner L, Gibson A, Sy J, Rundle AC, Hopkins JJ, Rubio RG, and Ehrlich JS (2012): Ranibizumab for diabetic macular edema. Ophthalmology, 119 (4): 789801.

10. Ruia S, Saxena S, Cheung CM, Gilhotra JS and Lai TY (2016): Spectral domain optical coherence tomography features and classification systems for diabetic macular edema: A Review. Ophthalmic Surg Lasers Imaging Retina, 47 (10): 908-913.

11. Somfai G, Tatrai E, Ferencz M, Puliafito CA and Cabrera D (2007): Quantifying retinal layer thickness changes in eyes with diabetic diffuse macular edema using optical coherence tomography. Investigative Ophthalmology \& Visual Science, 48 (1): 1426.

12. Trichonas G and Kaiser PK (2014): Optical coherence tomography imaging of macular edema. British Journal of Ophthalmology, 98 (2): $24-29$.

13. Tripathy K, Koushik, Sharma YR , Karthikeya R, Chawla R, Gogia V, Singh SK, Venkatesh $P$ and Vohra R (2015): Recent advances in management of diabetic macular edema. Current Diabetes Reviews, 11 (2): 7997.

14. Waris A, Asghar A, Yunus SM and Malakar $M$ (2015): Normal macular thickness measurements in normal eyes using fourier domain optical coherence tomography. Journal of Dental and Medical Sciences, 14 (2): 63-66.

15. Yasser $M$ and Heba $R$ (2013): Optical coherence tomography classification of diabetic cystoid macular edema. Clin Ophthalmol., 7 (1): 1731-1737. 


\section{المقارنة بين تغير ات سمك الطبقة الضفيرية الخارجية و}

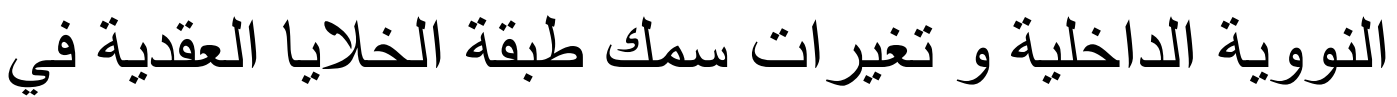

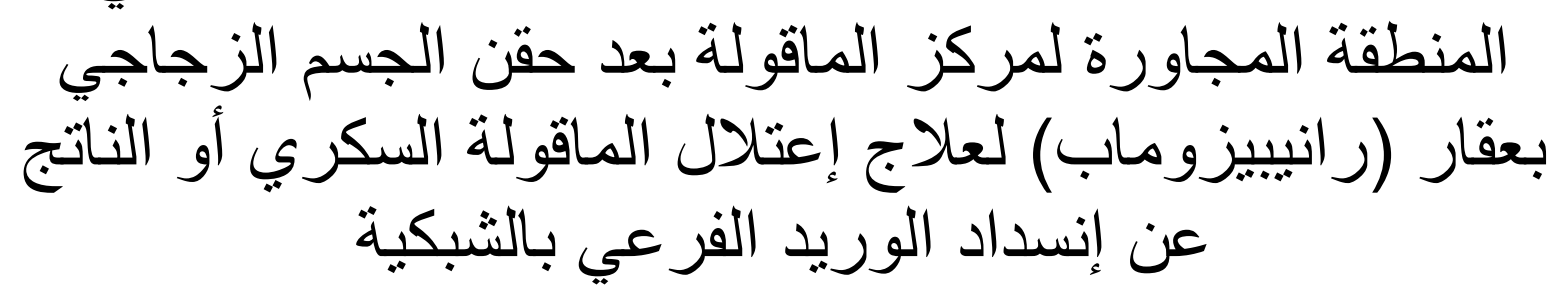

\section{مصطفى فريد محمد النكلاوي}

\section{قسم طب و جراحة العين- كلية الطب (بنين)- جامعة الأزهر}

خلقيـة البحث : يسـتخدم الماسـح البصـري المقطعي التو افقي في قيـاس سـكك الماقولـة في حـالات الإرنثاح الناتجة عن إعنلال الثبكية السكري أو إنسداد الوريد الفرعي بالثبكية، وقد سـاهم التقدم في أجهزة الماسـح البصـري المقطعي التو افقي مـؤخراً على تقسيم وقيـاس طبقات الثـبكية و در اسـة مـا يصيب كل طبقة على حدة، مدـا يسـاعد على تحسين فهم التر ابط بين العلامـات الإكلينيكيـة وطريقة تطور المرض في حالات الإرتشاح الكيسي و الإنتشاري للماقولة.

الهدف من البحث: مقارنة التغيرات التي تحدث في سمك الطبقة الضفيرية الخارجية و النووية الداخلية معاً بالتغير ات التي تحدث في طبقة الخلايـا العقديـة في النقطة الأكثر سمكاً بالمنطقة المجاورة لمركز الماقولة بعد حقن الجسم الزجاجي مرةً واحدةً بعقار رانيبيزوماب لعلاج إرتشاحات الماقولة الناتجة عن

$$
\text { إعتلال الشبكية السكري أو إنسداد الوريد الفرعي بالثبكية. }
$$

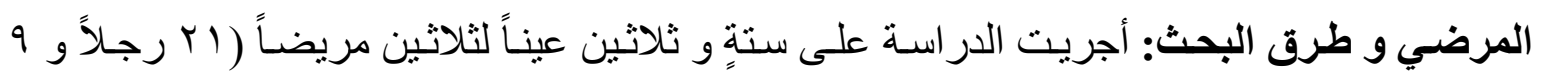

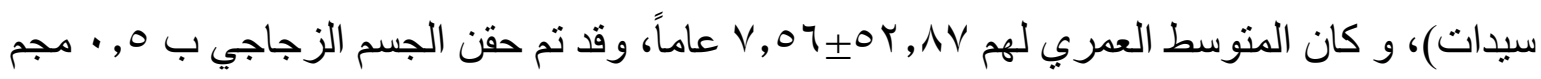
من عقار رانبييزوماب، و قد تم حقن العينين لستة من المرضسى و حقن عينٍ واحدة لأربعةٍٍ و عشرين مريضاً. و قد تم إستبعاد المرضى الذين سبق علاجهم بحقن الجسم الزجاجي، و المرضسى المصـابين بنزيف الجسم الزجاجي أو الثد الزجاجي الشبكي، و المرضسى المصـابين بـإعتلال الماقولة بسبب تقدم العمر أو قصر النظر الثديد. كما تم إستبعاد المرضى المصابين بدرجةٍ متقدمـةٍ مـن الجلوكومـا مفتوحسة الزاوية أو جلوكومـا التوعيـة المستحدثة. و قد تم عمل الفحص الإكلينيكي الكامل للعين قبل الحقن و خلال زيار ات المتابعة بعد الحقن، و قد تم أخذ قياسـات الثبكية باستخدام الماسـح البصـري المقطعي التو افقي قبل الحقن و بعد شهرٍ من حقن عقار رانيبيزوماب. وقد اشتملت هذه القياسات على قياس سمك مركز الماقولة و قياسـات المنطقة المجاورة لمركز الماقولة في قطاعاتها الأربعة عند النقطة الأكثر 
سمكاً ( . r ا ميكرون من مركز الشبكية) . و قد اشتملت قياسـات المنطقة المجاورة لمركز الماقولة

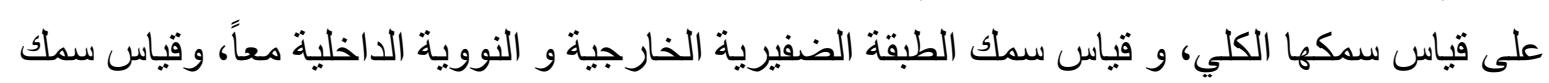
طبقة الخلايا العقدية منفردةً، و قياس سمك طبقة الخلايا العقدية و الضفيرية الداخلية معاً.

النتائج: إشتملت الدر اسة على ثلاثين عيناً مصابةً بإرنثاح الماقولة الناتج عن مر احل إعتلال الثبكية

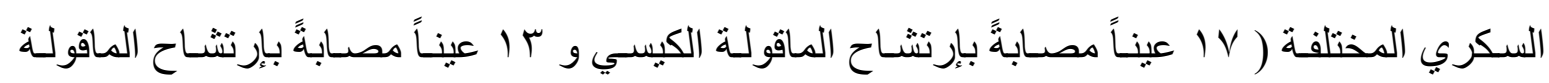

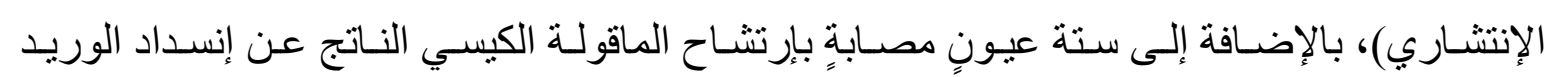

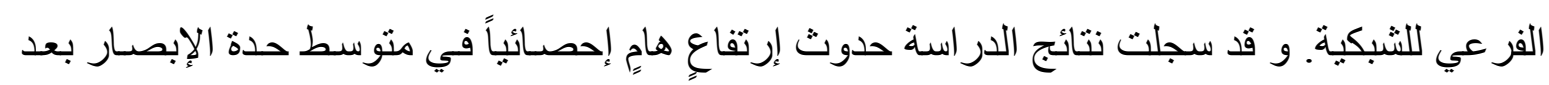

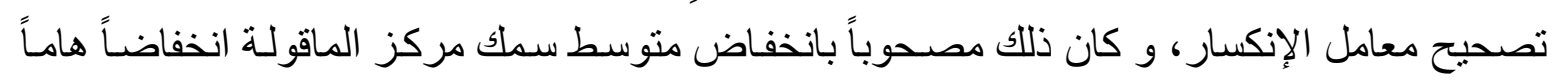

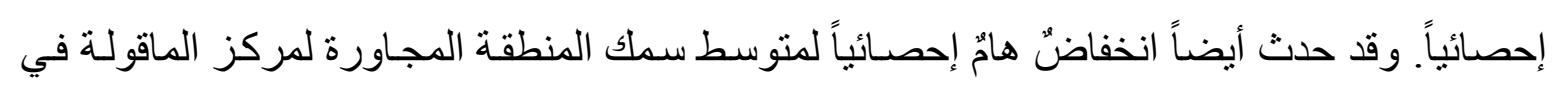

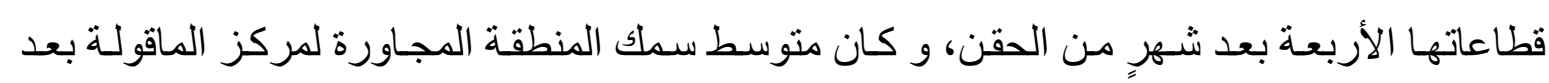

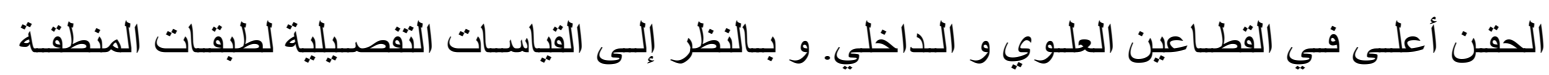

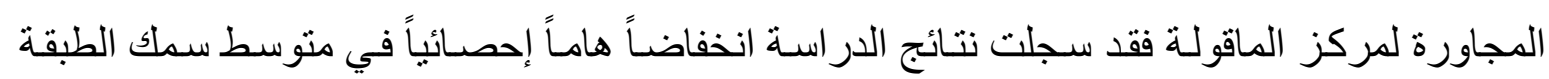

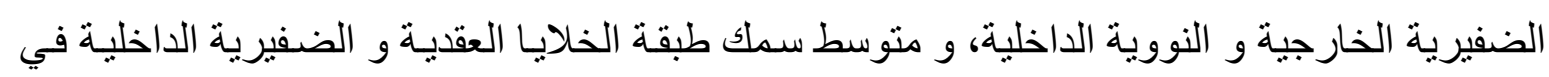

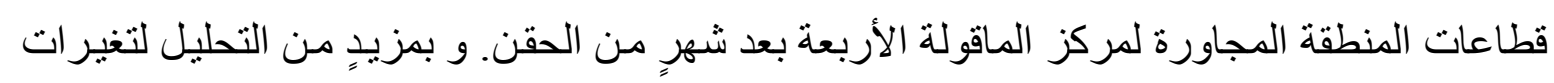

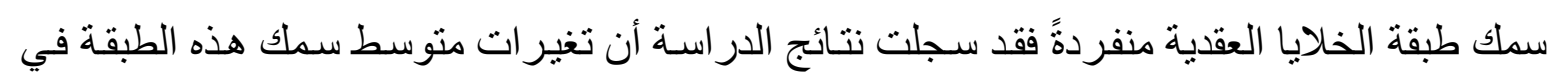

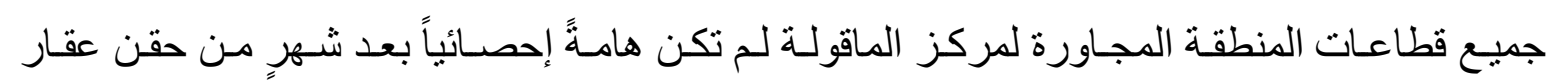

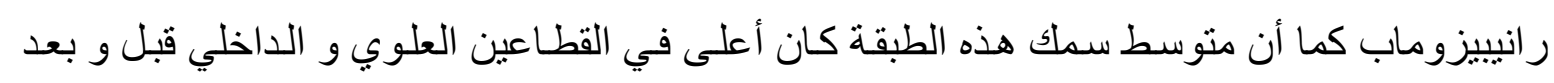
الحقن.

الاستنتاج: تم إنخفاض سمك الطبقة الضفيرية الخارجية و النووية الداخلية، كما تم إنخفاض سمك طبقة

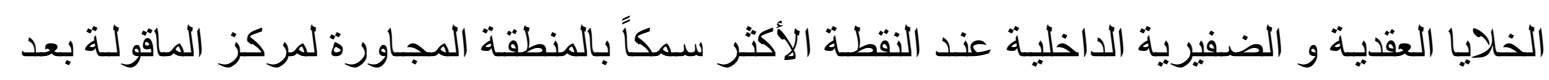

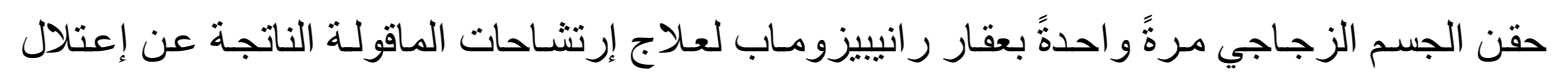

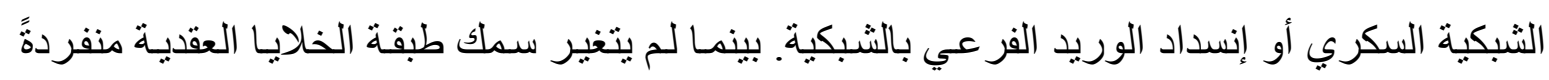

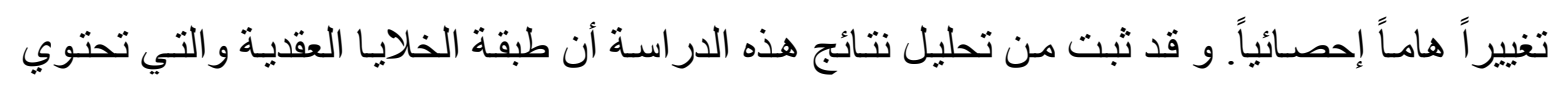

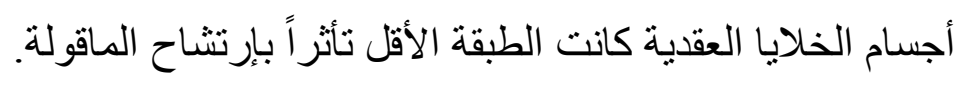

